\title{
Role of Clonal Integration among Different Environmental Conditions (A Review)
}

\author{
Wajahat Husain Jaafry, Dezhi Li, Syeda Amber Fatima, Muhammad Hassan* \\ School of Ecological and Environmental Sciences, East China Normal University, Shanghai, China \\ Email: *amber.fatima1985@gmail.com
}

How to cite this paper: Jaafry, W.H., Li, D.Z., Fatima, S.A. and Hassan, M. (2016) Role of Clonal Integration among Different Environmental Conditions (A Review). Natural Science, 8, 475-486.

http://dx.doi.org/10.4236/ns.2016.811049

Received: August 17, 2016

Accepted: November 19, 2016

Published: November 22, 2016

Copyright $\odot 2016$ by authors and Scientific Research Publishing Inc. This work is licensed under the Creative Commons Attribution International License (CC BY 4.0).

http://creativecommons.org/licenses/by/4.0/

\begin{abstract}
Most of the ecosystems are dominated by clonal species. The most unique feature of clonal plants is their capability for clonal integration (translocation of vital resources among connected ramets), implying that integration may play an essential role in their success. However, a general effect of clonal integration on plant performance is lacking. We conducted a text review on the effects of clonal integration on different habitats and species. Overall, clonal integration increased performance of clonal plants in different habitats. However clonal integration has also some limitations under stressful environments. Benefits of clonal integration may lack somehow when environmental stress increases. But connected ramets placed in unfavorable patches benefited more from integration compared to severed ramet placed in nutrient rich patches. Climate change and temperature increase have positive effects on biomass of clonal species.
\end{abstract}

\section{Keywords}

Clonal Integration, Habitats, Clonal Plants

\section{Introduction}

In natural environment many plant species acquire some extent of clonal growth named as "clonal plants" [1] [2]. In many ecosystems clonal plants are the core species and play a significant role in maintaining community organization and ecosystem functions [2] [3] [4]. The distinct ability of clonal plants to develop and reproduce themselves clonally had been a continuous interest for botanists. Thorough records of the morphology and composition of clonal plants exist from the middle of nineteenth century onwards. Afterward more research has targeted on the functionality of this interesting and complicated behaviour of modifying clonal plants to their local environment [5] [6] [7]. To explore deeply the distinct feature of clonal integration in clonal 
plants we decided to collect some closely relevant papers regarding clonal plants and review them for getting some new ideas and deficiencies in this field.

In terrestrial ecosystems, vital resources for plant conservation, growth and propagation, for instance nutrients, light and water, frequently are patchily dispersed in space and time [8] [9], even at levels admissible to plant individuals [10] [11] and its parts. Clonal plants escalate at right angel within the soil by virtue of stolons or rhizomes, and set up ramets in patches that may be different in resource inventory [10] [11]. Physiological integration can facilitate endurance and development of individual ramets endangered by opposition [12], grazing [4], environmental stress like wind erosion [13], sediment burial [14], salt stress [15], and light diminishing [16]. Development of younger ramets is facilitated by the flow of phloem and xylem contents from the older ramets to young ramet. By increment in age of younger ramet, the resource translocation from the parent ramet often declines, and the daughter ramets turn into self-regulating [17].

In natural habitats non-clonal plants frequently allocate additional resources to root system under low availability of soil nutrients to uptake more resources from the soil [18]. On contrary clonal plants adopt the reversed approach, by allocating additional resources to the growth of root organs placed within nutrient rich patches of soil [19] [20]. This strategy may enhance the overall performance of entire clone by translocating resources from source to sink (carbon, for example), and can be shared through ramets placed elsewhere. Main target of this review article is to explain the basic mechanism regarding clonal integration under different environmental conditions, and the limitations of clonal integration under different environmental stresses. The new ideas and research gaps still need to be explored in the field of ecology.

\section{Role of Clonal Integration at Different Environmental Stress}

Plants may adjust biomass allocation arrangement in response to the habitat [9]. Accessibility of soil nutrients is one of key factors that may determine resource allotment patterns [21]. One assumption is that plants in nutrient poor environments should allocate relatively more resources to roots to enhance their uptake capacity for these insufficient soil resources [8] [22]. Allocation of nutrient resources to different habitats has been the basic concept of life-history theory [11] [23], and allocation patterns mostly decide the capability of plants to detain resources, to contest with neighbours [24].

According to theoretical model of [25] in clonal plants clonal integration among connected ramets enhance entire growth and survivorship extensively more under heterogeneous than under homogeneous resource environment. One explanation for this may be clonal plants might be able to improve the efficiency of their resource consumption by distributing their resources along rhizome systems from more favorably placed nutrient rich ramets to ramets in less favorable micro-environments [26]. A further possible reason is that the resource acquirement of whole clonal fragments could be strengthen by raise up the photosynthetic capacity or resource uptake capacity in diverse environments (i.e. division of labor or plasticity behavior could be advanta- 
geous) [8] [27]. Many studies projected that clonal integration can encourage resource exploring performance, whereby a clone can utilize favorable nutrient rich patches or avoid unfavorable nutrient poor patches by the selective positioning of its ramets [25] [28].

Sharing of resources by means of clonal integration control survival, development, physiology and morphology of ramets, and as a result give benefits to the genet as a whole [29] [30]. Available nutrient and intensity of light are two essential plant resources that are frequently negatively associated in the field [29] [30]. The effect of clonal integration on plant performance may differ along with species and habitats [22] [31].

Soil conditions (soil nitrogen, available soil phosphorus and soil $\mathrm{pH}$ ) had no effect on the biomass allocation of daughter ramet, in the Black locust when the ramets were remained interconnected. After severing of root connections, however, biomass allocation by the daughter ramets of black locust increased greatly in response to soil nitrogen and available phosphorus. Therefore, that result is inconsistent with the general behaviour of other clonal plants to response of soil heterogeneity [32].

All together, these results propose that in connected clones the nitrogen and phosphorus requirements of the daughter ramets are provided mainly by the (much superior) parent ramets during clonal integration. In these situations, daughter ramets are mostly insensitive to soil conditions. When the daughter ramet was detached from parent ramet, then, daughter ramets had no supply of nutrients by parent ramet so the younger ramet were required to allocate resources to root growth to get soil nutrients adequate to sustain growth, a behavior persistent with that of a non-clonal plant [18]. The variation among ramet size seems to be a key explanation of resource allocation. Well established parent ramet may easily share the nutrient requirement when young ramet is small. Conceivably morphological plasticity between interlinked ramets in response to nutrient rich patch has a selective benefit only when their size difference is comparatively small [32]. Nitrogen fixing shrubs that grow under the canopy of forest for example, soil nitrogen can be abundant but intensity of light may be low. On the contrary, in open field situations, availability of light is abundant but soil nutrients may be inadequate [33].

In these kinds of conditions, resource utilization by the genet can be better if individual ramets can take advantage of locally abundant resources by escalating growth in those organs valuable to resource uptake. For instance, by allocating more biomass to aboveground organs in segments of high light intensity, carbon can be fixed more by photosynthesis assuming that other potentially limiting resources can be translocated by ramets situated somewhere else. On the other hand, soil nutrient uptake can be enhanced by allocating more biomass to the root system of the plant located in patches with rich soil nutrient supply but low light intensity [14] [34] [35].

\section{Role of Clonal Integration in Grazed Plants}

Plant forage consequently leads to the reduction of photosynthetic tissue, however, 
which, most of the time outcome in a relative decrease of growth in herbaceous species [36] [37]. More often herbaceous plants are bared to different intensity of grazing.

In the study of Wang et al., 2009, they found when rhizomes were connected size increased significantly, heavy clipping increased leaf and biomass density of both species Bromus and Psammochloa and also increased leaf and biomass density of Psammochloa under moderate clipping. Their results support that clonal integration has an essential role to indemnify the compensatory growth of clonal plants. Most probably this was due to one reason that clipped ramets picked up carbohydrates during clonal integration from their associated non clipped ramets, and as a result the adverse effects of clipping were extensively minimized. Under artificial herbivory clonal integration was also established to indemnify the unfavorable effects of defoliation on Aster lanceolatus and Solidago canadensis in old fields [38] and Ipomoeapes-caprae in beach dunes [39] (see Table 1).

Daughter ramets of invasive plant Alternanthera philoxeroides were also benefited from clonal integration by its mother ramet in response to artificial defoliation. Despite of defoliation intensity well established mother ramet translocated their resources to their interconnected daughter ramets to facilitate the growth of new tissues. This result was similar as the previous studies (from well-established older ramet to younger ramets) sharing of resources [13] [40] (Table 1). Many other invasive plants and A.philoxeroides promote the formation of young ramets and enhance the growth and clonal proliferation of young daughter ramet under stressful environments. These results specify that clonal integration may be significant in tolerating invasive clonal plants to discover more resources and may consequently raise their invasiveness in natural environments [41] [42].

Table 1. Role of clonal integration under defoliation.

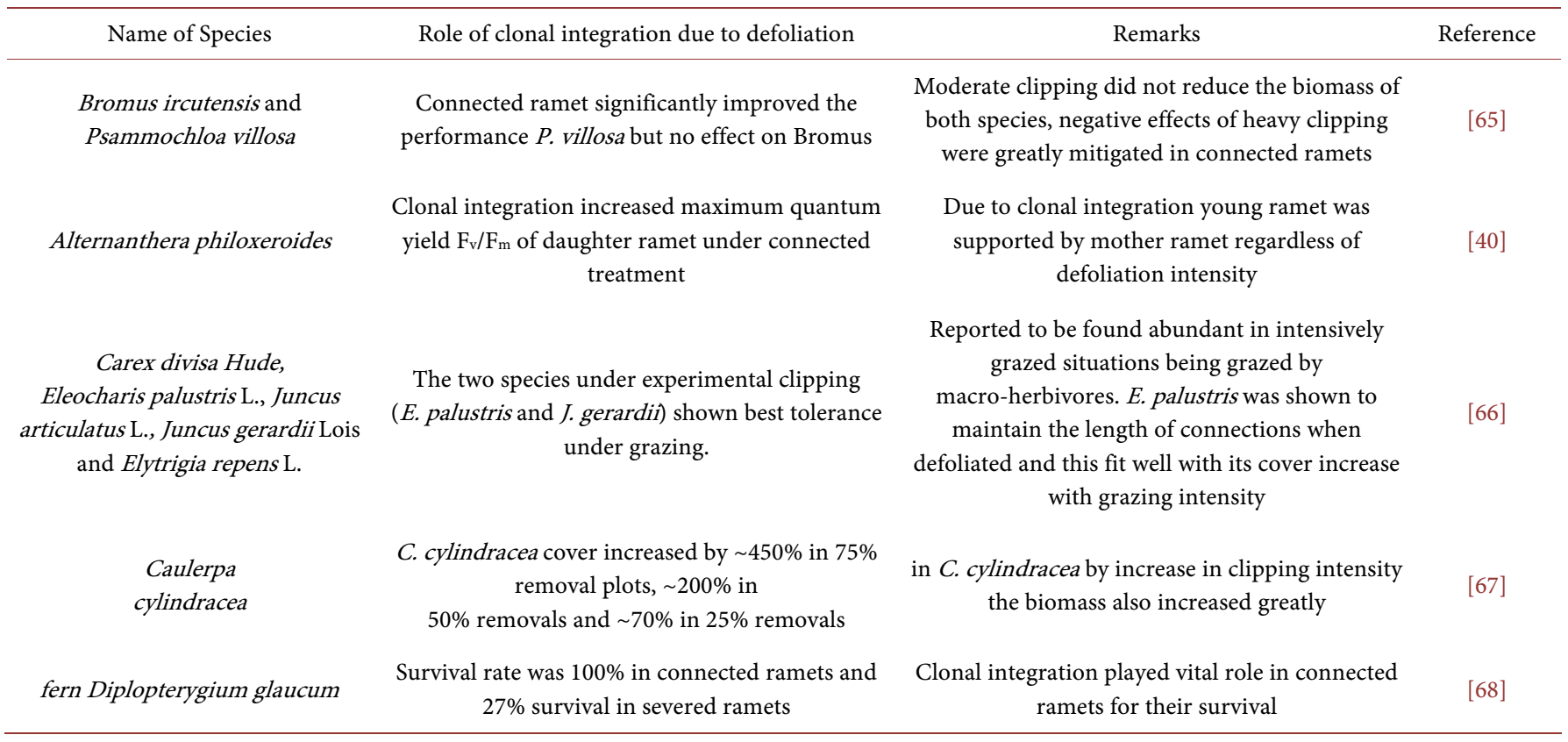




\section{Role of Clonal Integration Due to Climate Change in Wetlands}

In estuarine habitats, many environmental factors may manipulate plant growth, existence, and competing interactions. Elements that may fluctuate geographically within wetlands include water depth, salinity level, flooding interval, SOM (soil organic matter), and sediment size of soil and nutrient abundance. Intraspecific variation in salt tolerance has been described in wetland herbaceous species [43] [44]. Among terrestrial ecosystems, the consequences of global warming on plant chemical reaction and growth can be changed by exposing with other environmental aspects, particularly root section moisture content of soil (Harte and Shaw, 1995; Sherry et al., 2008) and available soil nutrient [7] [45] [46] (see Table 2).

Increase in average temperature globally may disturb plant population in many terrestrial ecosystems [46] [47] [48] [49]. By the last century, the average atmospheric temperature has elevated by $0.74^{\circ} \mathrm{C}$ [50]. By the end of the 21 st century it is expected in East Asia, that there would be increase in air temperature by $3.3^{\circ} \mathrm{C}$ [51]. While climate change may generally enhance the biomass production of grass population [49], as a result of climate change the response is species specific according to their functional type (Table 2).

\section{Role of Clonal Integration at Different Altitudes}

Many environmental factor changes by increase in altitude, for example, lower temperature level higher solar radiation with higher exposure to the short wavelength radiations and lower atmospheric pressure. These factors create environmental stress more severe for growth of plants at higher altitude as compared to low altitude [52]. It has been reported that there is a higher extent of clonal integration in cold environment by using isotopic tracer analysis [53].

Alpine plants at high altitude, surviving in their origin with harsh winds, low temperature, exposure to high radiation levels and low fractional pressures of $\mathrm{CO}_{2}$, have slow growing rate also in the common garden culture. These plants seem to be naturally

Table 2. Role of clonal integration in wetlands.

\begin{tabular}{|c|c|c|c|}
\hline Name of species & Role of clonal integration in wetlands & Remarks & References \\
\hline Spartina alterniflora & $\begin{array}{c}\text { Biomass allocation was in controls or in shallow and } \\
\text { deep water treatments were } 119 \%, 108 \% \text { and } 149 \% \\
\text { higher than severed in old ramets }\end{array}$ & $\begin{array}{l}\text { Clonal integration enhance the growth of } S \text {. } \\
\text { alterniflora under flooding stress }\end{array}$ & {$[69]$} \\
\hline Carex praeclara & $\begin{array}{c}\text { By increase in sand burial intensity the mother ramet } \\
\text { supported young ramet through increase in } \\
\text { photosynthetic efficiency }\end{array}$ & $\begin{array}{l}\text { With severing treatment biomass allocation } \\
\text { was affected due to sand burial }\end{array}$ & {$[70]$} \\
\hline Spartina alterniflora & $\begin{array}{l}\text { At } 5 \%, 20 \% \text { and } 35 \% \text { substrate salinity level the } \\
\text { growth and sexual reproduction decreased with } \\
\text { increment in salinity level }\end{array}$ & $\begin{array}{l}\text { Clonal integration very limited role on salinity } \\
\text { and the growth and sexual } \\
\text { reproduction of mother and daughter ramets }\end{array}$ & {$[71]$} \\
\hline Scirpus mariqueter & $\begin{array}{l}\text { Reciprocal translocation of resources were found in } \\
\text { creekside communities within old and young ramets }\end{array}$ & $\begin{array}{l}\text { In response to disturbance clonal integration } \\
\text { may play a significant role }\end{array}$ & {$[72]$} \\
\hline
\end{tabular}


slow growing [52] [54]. Clonal integration is stronger at high altitude than low. At high altitude strong clonal integration seems to be more important in the perspective of ecology for the clonal plants that grow at higher altitude than lower habitats (Table 3).

According to Chen et al., 2004 overall effects of population on growth of the whole clonal section, for instance biomass, total stolon length and total number of ramets, were significant with increase in altitude. All of these factors were significantly higher for plants located at $3944 \mathrm{~m}$ above sea level (a.s.l.) than $1800 \mathrm{~m}$ (a.s.l.) Apart from altitude severing treatment had a negative impact on biomass and total stolon length of entire clonal fragments. When the ramets were remained connected the total stolon length increased significantly from two different altitudes, higher biomass and number of ramets for plants only from higher altitudes than lower [14].

Plants that grow under stressful environments most of the time have naturally low relative growth rate (RGR) comparatively to the plants which grow under favorable conditions [24]. Total biomass, total stolon length and number of ramets were significantly higher for plants at lower altitude $1800 \mathrm{~m}$ a.s.l. than from $3944 \mathrm{~m}$ a.s.l. It can be referred that plants at higher altitude have lower specific leaf area. According to patch scale higher resource sharing through clonal integration may lead to improved performance of whole clone [55] (see Table 3).

\section{Clonal Invasions and Its Implications}

Clonal growth has been repeatedly referred to as a characteristic that grants to plant invasiveness [56] [57] [58]. In fact, a substantial amount of the most invasive plant species globally having the ability of clonal growth [59]. The advantages of clonal plant species could have over non-clonal ones during invasion may comprise their capability to vegetative reproduction and tolerate in the deficiency of suitable pollinators and the ability to efficiently and rapidly cover a location through clonal growth [59] [60].

Although clonality is associated with invasiveness, most of the clonal plant species have not turn into invasive, and it is unidentified which behavior make some clonal species more invasive than others. Up till now, the mechanisms that clarify the dominancy of invasive species remain unclear [7] [61]. Some plant properties, such as clonal growth, could explain the success of invasive species [59] [62]. The knowledge about

Table 3. Clonal integration at different altitudes.

\begin{tabular}{ccc}
\hline Name of species & Clonal integration at different altitudes & Remarks \\
Duchesnea indica & $\begin{array}{c}\text { Benefit of clonal integration was observed more at high } \\
\text { altitude than lower, } D \text {. indica was more responsive to } \\
\text { severing treatment at high altitude }\end{array}$ & $\begin{array}{c}\text { Clonal integration is more stronger at high } \\
\text { altitude than low }\end{array}$ \\
Chara vulgaris & $\begin{array}{c}\text { The effect of temperature increase the population of lower } \\
\text { altitude were seem to be more tolerant than high altitude }\end{array}$ & $\begin{array}{c}\text { Global warming will be negatively correlated with } \\
\text { clonal integration at higher altitude than low }\end{array}$ \\
Fragaria vesca & [3fect of clonal integration on two populations of \\
F. vesca from different altitudes was same & $\begin{array}{c}\text { However the performance of the whole clonal } \\
\text { fragment seemed to be better at higher altitude } \\
\text { than low }\end{array}$ & [14] \\
\hline
\end{tabular}


biological invasions is a quickly expanding field in ecology. Globally biological invasions characterize one of the most severe environmental threats, because non-native invasive species can alter the balance and functioning of native communities, and dislocate native plants with the subsequent loss of biodiversity [63].

In natural habitats, more often clonal plants are dominant species in terrestrial ecosystems, and have a significant role in the functioning of many plant communities and ecological units [64]. Main features related to clonal growth such as physiological integration, phenotypic plasticity, habitat selection and division of labor permit clonal plants to compete effectively in a wide range of habitats [27] [34]. In spite of that several of the most aggressive intrusive plant species execute clonal growth.

\section{Conclusion and Future Recommendations}

Role of clonal integration among the different habitats is species specific and its intensity varies in response to the degree of stress. In clonal plants there are many aspects of research which must be studied, we point out here a few of them. For further knowledge in the perspective of biodiversity more research should be conducted to control the biological invasion in cost effective way. Why some invasive species are more aggressive than other invasive clonal species? How does different soil $\mathrm{pH}$ affect clonal growth in different environmental condition? Furthermore, previous research has mainly focused on heterogeneous resource distribution where two resources are negatively correlated but significance of clonal integration in homogeneous resources is somewhat overlooked (but see Dong et al. 2015b; Zhang et al. 2016). Role of clonal integration should also be tested under different light regimes $\mathrm{R}$ and FR (red and far red light) intensities and its response of clonal species in forest understory. There is also no well-known research about clonal plant mutual facilitation mechanism, and how different kinship and siblings levels of seeds respond to the facilitation.

\section{Acknowledgements}

This study was supported by East China Normal University online library for downloading articles.

\section{References}

[1] Van Groenendael, J. and De Kroon, H. (1990) Clonal Growth in Plants: Regulation and Function. SPB Academic Publishing, Hague Netherlands, 196 p.

[2] Klimeš, L., Klimešová, J., Hendriks, R. and van Groenendael, J. (1997) Clonal Plant Architecture: A Comparative Analysis of Form and Function. The Ecological and Evolutionary Consequences of Clonality for Plant, 1-29.

[3] Jonsdottir, I.S. and Watson, M.A. (1997) Extensive Physiological Integration: An Adaptative Trait in Resource-Poor Environments? The Ecological and Evolutionary Consequences of Clonality for Plant, 109-136.

[4] Wilsey, B. (2002) Clonal Plants in a Spatially Heterogeneous Environment: Effects of Integration on Serengeti Grassland Response to Defoliation and Urine-Hits from Grazing Mammals. Plant Ecology, 159, 15-22. http://dx.doi.org/10.1023/A:1015556816307 
[5] de Kroon, H. and Van Groenendael, J. (1997) The Ecology and Evolution of Clonal Plants. Backhuys Publishers, Leiden, 456.

[6] Dong, B.C., Alpert, P., Zhang, Q. and Yu, F.H. (2015) Clonal Integration in Homogeneous Environments Increases Performance of Alternanthera philoxeroides. Oecologia, 179, 393403. http://dx.doi.org/10.1007/s00442-015-3338-y

[7] Zhang, H., Liu, F., Wang, R. and Liu, J. (2016) Roles of Clonal Integration in Both Heterogeneous and Homogeneous Habitats. Frontiers in Plant Science, 7, 1-8.

[8] Alpert, P. (1996) Nutrient Sharing in Natural Clonal Fragments of Fragaria Chiloensis. Journal of Ecology, 84, 395-406. http://dx.doi.org/10.2307/2261201

[9] Steud, Z., Li, D., Ito, M. and Okajima, T. (2004) Effects of Soil Nutrient Heterogeneity on the Growth of Plants under the Various Distributions and Levels of Nutrients in Zoysia japonica Steud. Grassland and Science, 51, 41-44.

[10] Jackson, R.B. and Caldwell, M.M. (1993) The Scale of Nutrient Heterogeneity Around Individual Plants and Its Quantification with Geostatistics. Ecology, 74, 612-614. http://dx.doi.org/10.2307/1939320

[11] Stuefer, H., DeKroon, J.F. and During, H. (1996) Exploitation of Environmental Heterogeneity by spatial Division of Labour in a Clonal Plant. Functional Ecology, 10, 328-334. http://dx.doi.org/10.2307/2390280

[12] Pennings, S.C. and Callaway, R.M. (2000) The Advantages of Clonal Integration under Different Ecological Conditions: A Community-Wide Test. Ecology, 81, 709-716. http://dx.doi.org/10.1890/0012-9658(2000)081[0709:TAOCIU]2.0.CO;2

[13] Wang, N., Yu, F.H., Li, P.X., He, W.M., Liu, J., Yu, G.L., Song, Y.B. and Dong, M. (2009) Clonal Integration Supports the Expansion from Terrestrial to Aquatic Environments of the Amphibious Stoloniferous Herb Alternanthera philoxeroides. Plant Biology, 11, 483-489. http://dx.doi.org/10.1111/j.1438-8677.2008.00133.x

[14] Chen, J.-S., Yu, D.A.N., Liu, Q. and Dong, M. (2004) Clonal Integration of the Stoloniferous Herb Fragaria vesca from Different Altitudes in Southwest China. Flora-Morphology, Distribution, Functional Ecology of Plants, 199, 342-350. http://dx.doi.org/10.1078/0367-2530-00162

[15] Evans, J.P. and Whitney, S. (1992) Clonal Integration across a Salt Gradient by a Nonhalophyte, Hydrocotyle bonariensis (Apiaceae). American Journal of Botany, 79, 1344-1347. http://dx.doi.org/10.2307/2445132

[16] Stuefer, J.F. and Hutchings, M.J. (1994) Environmental Heterogeneity and Clonal Growth: A Study of the Capacity for Reciprocal Translocation in Glechoma hederacea L. Oecologia, 100, 302-308. http://dx.doi.org/10.1007/BF00316958

[17] Bullock, J.M., Mortimer, A.M. and Begon, M. (1994) Physiological Integration among Tillers of Holcus lanatus -Age-Dependence and Responses to Clipping and Competition. New Phytologist, 128, 737-747. http://dx.doi.org/10.1111/j.1469-8137.1994.tb04037.x

[18] Qu, L., Quoreshi, A.M. and Koike, T. (2003) Root Growth Characteristics, Biomass and Nutrient Dynamics of Seedlings of Two Larch Species Raised under Different Fertilization Regime. Plant Soil, 255, 293-302. http://dx.doi.org/10.1023/A:1026159709246

[19] Huber, H. and Stuefer, J.F. (1997) Shade-Induced Changes in the Branching Pattern of a Stoloniferous Herb: Functional Response or Allometric Effect? Oecologia, 110, 478-486. http://dx.doi.org/10.1007/s004420050183

[20] Chen, J.S., Lei, N.F., Yu, D. and Dong, M. (2006) Differential Effects of Clonal Integration on Performance in the Stoloniferous Herb Duchesnea indica, as Growing at Two Sites with Different Altitude. Plant Ecology, 183, 147-156. 
http://dx.doi.org/10.1007/s11258-005-9013-3

[21] Roiloa, S.R., Rodríguez-Echeverría, S., Freitas, H. and Retuerto, R. (2013) DevelopmentallyProgrammed Division of Labour in the Clonal Invader Carpobrotus edulis. Biological Invasions, 15, 1895-1905. http://dx.doi.org/10.1007/s10530-013-0417-z

[22] Alpert, P. (1999) Effects of Clonal Integration on Plant Plasticity in Fragaria chiloensis. Plant Ecology, 141, 99-106. http://dx.doi.org/10.1023/A:1009823015170

[23] Hutchings, M.J. and Wijesinghe, D.K. (1997) Patchy Habitats, Division of Labour and Growth Dividends in Clonal Plants. Trends in Ecology \& Evolution, 12, 390-394. http://dx.doi.org/10.1016/S0169-5347(97)87382-X

[24] Lambers, H. and Poorter, H. (1992) Inherent Variation in Growth Rate between Higher Plants: A Search for Ecological Causes and Consequences. Advances in Ecological Research, 23, 187-261. http://dx.doi.org/10.1016/S0065-2504(08)60148-8

[25] Caraco, T. and Kelly, C.C.K. (1991) On the Adaptive Value of Physiological Integraton in Colonal Plants. Ecology, 72, 81-93. http://dx.doi.org/10.2307/1938904

[26] Poor, A., Hershock, C., Rosella, K. and Goldberg, D.E. (2005) Do Physiological Integration and Soil Heterogeneity Influence the Clonal Growth and Foraging of Schoenoplectus pungens? Plant Ecology, 181, 45-56. http://dx.doi.org/10.1007/s11258-005-2429-y

[27] Roiloa, S.R., Alpert, P., Tharayil, N., Hancock, G. and Bhowmik, P.C. (2007) Greater Capacity for Division of Labour in Clones of Fragaria chiloensis from Patchier Habitats. Journal of Ecology, 95, 397-405. http://dx.doi.org/10.1111/j.1365-2745.2007.01216.x

[28] Slade, A.J. and Hutchings, M.J. (1987) Clonal Integration and Plasticity in Foraging Behaviour in Glechoma hederacea. Journal of Ecology, 75, 1023-1036. http://dx.doi.org/10.2307/2260311

[29] Ecosystem, F. and Simulation, M. (2002) Morphological Plasticity of White Clover (Trifolium repens L.) in Response to Spatial and Temporal Resource Heterogeneity. Oecologia, 130, 231-238. http://dx.doi.org/10.1007/s004420100791

[30] Liao, M., Yu, F., Song, M., Zhang, S., Zhang, J. and Dong, M. (2003) Plasticity in R/S Ratio, Morphology and Fitness-Related Traits in Response to Reciprocal Patchiness of Light and Nutrients in the Stoloniferous Herb, Glechoma longituba L. Acta Oecologica, 24, 231-239. http://dx.doi.org/10.1016/j.actao.2003.07.001

[31] D'Hertefeldt, T. and Falkengren-Grerup, U. (2002) Extensive Physiological Integration in Carex arenaria and Carex disticha in Relation to Potassium and Water Availability. New Phytologist, 156, 469-477. http://dx.doi.org/10.1046/j.1469-8137.2002.00529.x

[32] Zhang, X.Q., Liu, J., Welham, C.V.J., Liu, C.C., Li, D.N., Chen, L. and Wang, R.Q. (2006) The Effects of Clonal Integration on Morphological Plasticity and Placement of Daughter Ramets in Black Locust (Robinia pseudoacacia). Flora-Morphology, Distribution, Functional Ecology of Plants, 201, 547-554. http://dx.doi.org/10.1016/j.flora.2005.12.002

[33] Alpert, P. and Mooney, H.A. (1986) Resource Sharing among Ramets in the Clonal Herb, Fragaria chiloensis. Oecologia, 70, 227-233. http://dx.doi.org/10.1007/BF00379244

[34] Alpert, P. and Stuefer, J.E. (1997) Division of Labour in Clonal Plants. In: de Kroon, H. and van Groenendael, J., Eds., The Ecology and Physiology of Clonal Plants, Backhuys, Leiden, 137-154.

[35] Yu, F., Chen, Y. and Dong, M. (2002) Clonal Integration Enhances Survival and Performance of Potentilla anserina, Suffering from Partial Sand Burial on Ordos Plateau, China. Evolutionary Ecology, 15, 303-318. http://dx.doi.org/10.1023/A:1016032831038

[36] Ferraro, D. and Oesterheld, M. (2002) Effect of Defoliation on Grass Growth. A Quantitative Review. Oikos, 98, 125-133. http://dx.doi.org/10.1034/j.1600-0706.2002.980113.x 
[37] Geissler, K. and Gzik, A. (2008) Ramet Demography and Ecological Attributes of the Perennial River Corridor Plant Cnidium Dubium (Schkuhr) Thell. (Apiaceae). Flora-Morphology, Distribution, Functional Ecology of Plants, 203, 396-408. http://dx.doi.org/10.1016/j.flora.2007.05.008

[38] Schmid, B. and Bazzaz, F.A. (1987) Clonal Integration and Population Structure in Perennials: Effects of Severing Rhizome Connections. Ecology, 68, 2016-2022.

http://dx.doi.org/10.2307/1939892

[39] Bach, C.E. (2000) Effects of Clonal Integration on Response to Sand Burial and Defoliation by the Dune Plant IPOMOEA Pes-Caprae (Convolvulaceae). Australian Journal of Botany, 48, 159-166. http://dx.doi.org/10.1071/BT98030

[40] You, W., Yu, D., Xie, D., Han, C. and Liu, C. (2014) The Invasive Plant Alternanthera philoxeroides Benefits from Clonal Integration in Response to Defoliation. Flora-Morphology, Distribution, Functional Ecology of Plants, 209, 666-673. http://dx.doi.org/10.1016/j.flora.2014.09.008

[41] Liu, J., He, W.M., Zhang, S.M., Liu, F.H., Dong, M. and Wang, R.Q. (2008) Effects of Clonal Integration on Photosynthesis of the Invasive Clonal Plant Alternanthera philoxeroides. Photosynthetica, 46, 299-302. http://dx.doi.org/10.1007/s11099-008-0054-4

[42] You, W., Yu, D., Liu, C., Xie, D. and Xiong, W. (2013) Clonal Integration Facilitates Invasiveness of the Alien Aquatic Plant Myriophyllum aquaticum L. under Heterogeneous Water Availability. Hydrobiologia, 718, 27-39. http://dx.doi.org/10.1007/s10750-013-1596-4

[43] Blits, K.C. and Gallagher, J.L. (1991) Morphological and Physiological Responses to Increased Salinity in Marsh and Dune Ecotypes of Sporobolus virginicus (L.) Kunth. Oecologia, 87, 330-335. http://dx.doi.org/10.1007/BF00634587

[44] Enberg, A. and Wu, L. (1995) Selenium Assimilation and Differential Response to Elevated Sulfate and Chloride Salt Concentrations in Two Saltgrass Ecotypes. Ecotoxicology and Environmental Safety, 32, 171-178. http://dx.doi.org/10.1006/eesa.1995.1099

[45] Hobbie, S.E., Nadelhoffer, K. and Högberg, P. (2002) A Synthesis: The Role of Nutrients as Constraints on Carbon Balances in Boreal and Arctic Regions. Plant and Soil, 242, 163-170. http://dx.doi.org/10.1023/A:1019670731128

[46] Wu, Z., Dijkstra, P., Koch, G.W., Peñuelas, J. and Hungate, B.A. (2011) Responses of Terrestrial Ecosystems to Temperature and Precipitation Change: A Meta-Analysis of Experimental Manipulation. Global Change Biology, 17, 927-942. http://dx.doi.org/10.1111/j.1365-2486.2010.02302.x

[47] Harte, J. and Shaw, R. (1995) Shifting Dominance within a Montane Vegetation Community: Results of a Climate-Warming Experiment. Science, 267, 876-880. http://dx.doi.org/10.1126/science.267.5199.876

[48] Avenue, O.S. and Group, R. (2001) Plant Responses to Experimental Warming in a Montane Meadow. Ecology, 82, 637-648. http://dx.doi.org/10.1890/0012-9658(2001)082[0637:PRTEWI]2.0.CO;2

[49] Lin, D., Hu, L., You, H., Sarkar, D., Xing, B. and Shetty, K. (2010) Initial Screening Studies on Potential of High Phenolic-Linked Plant Clonal Systems for Nitrate Removal in Cold Latitudes. Journal of Soils and Sediments, 10, 923-932. http://dx.doi.org/10.1007/s11368-010-0214-6

[50] IPPC (2007) Contribution of Working Groups I, II and III to the Fourth Assessment Report of the Intergovernmental Panel on Climate Change. 104.

[51] Solomon, S., Qin, D., Manning, M., Chen, Z., Marquis, M., Averyt, K.B., Tignor, M. and Miller, H.L. (2007) The Physical Science Basis. Contribution of Working Group I to the 
Fourth Assessment Report of the Intergovernmental Panel on Climate Change, IPCC 2007 Climate Change.

[52] Körner, C. and Menendez-Riedl, S.P. (1989) The Significance of Developmental Aspects in Plant Growth Analysis. In: Lambers, H., Cambridge, M.L., Königs, H. and Pons, T.L., Eds., Causes and Consequences of Variation in Growth Rate and Productivity of Higher Plants, SPB Academic Publishing, Hague, 141-157.

[53] Jonsdottir, I. (1990) Intraclonal Translocation of Ammonium and Nitrate Nitrogen in $\mathrm{Ca}$ rex bigelowii Torr. ex Schwein. Using $15 \mathrm{~N}$ and Nitrate Reductase Assays. New Phytologist, 114, 419-428. http://dx.doi.org/10.1111/j.1469-8137.1990.tb00409.x

[54] Atkin, O. and Day, D. (1990) A Comparison of the Respiratory Processes and Growth Rate of Selected Australian Alpine and Related Lowland Plant Species. Functional Plant Biology, 17, 517-526. http://dx.doi.org/10.1071/pp9900517

[55] Holzapfel, C. and Alpert, P. (2003) Root Cooperation in a Clonal Plant: Connected Strawberries Segregate Roots. Oecologia, 134, 72-77.

http://dx.doi.org/10.1007/s00442-002-1062-x

[56] Reichard, S.H. and Hamilton, C.W. (1997) Predicting Invasions of Woody Plants Introduced into North America. Conservation Biology, 11, 193-203. http://dx.doi.org/10.1046/j.1523-1739.1997.95473.x

[57] Lloret, F., Médail, F., Brundu, G., Camarda, I., Moragues, E., Rita, J., Lambdon, P. and Hulme, P.E. (2005) Species Attributes and Invasion Success by Alien Plants on Mediterranean Islands. Journal of Ecology, 93, 512-520. http://dx.doi.org/10.1111/j.1365-2745.2005.00979.x

[58] Speek, T.A.A., Lotz, L.A.P., Ozinga, W.A., Van Der Putten, W.H. and Schamine, J.H.J. (2011) Factors Relating to Regional and Local Success of Exotic Plant Species in Their New Range. Diversity and Distributions, 17, 542-551. http://dx.doi.org/10.1111/j.1472-4642.2011.00759.x

[59] Liu, J., Dong, M., Miao, S.L., Li, Z.Y., Song, M.H., Qing, R. and Wang, R.Q. (2006) Invasive Alien Plants in China: Role of Clonality and Geographical Origin. Biological Invasions, 8, 1461-1470. http://dx.doi.org/10.1007/s10530-005-5838-x

[60] Pyšek, P. and Richardson, D.M. (2007) Traits Associated with Invasiveness in Alien Plants: Where Do We Stand? Biological Invasions, 193, 97-125. http://dx.doi.org/10.1007/978-3-540-36920-2 7

[61] Alpert, P., Bone, E. and Holzapfel, C. (2000) Invasiveness, Invasibility and the Role of Environmental Stress in the Spread of Non-Native Plants. Perspectives in Plant Ecology, Evolution and Systematics, 3, 52-66. http://dx.doi.org/10.1078/1433-8319-00004

[62] Roiloa, S.R., Rodríguez-Echeverría, S., de la Peña, E. and Helena, F. (2010) Physiological Integration Increases the Survival and Growth of the Clonal Invader Carpobrotus edulis. Biological Invasions, 12, 1815-1823. http://dx.doi.org/10.1007/s10530-009-9592-3

[63] Vitousek, P., D’Antonio, C.M., Loope, L.L. and Westbrooks, R. (1996) Biological Invasions as Global Environmental Change. American Scientist, 84, 468-478.

[64] Klimes, L., Klimesová, J., Hendriks, R. and van Groenendael, J. (1997) Clonal Plant Architecture: A Comparative Analysis of Form and Function. In: de Kroon, H. and van Groenendael, J., Eds., The Ecology and Evolution of Clonal Plants, Backhuys Publishers, Leiden, 1-29.

[65] Liu, H.D., Yu, F.H., He, W.M., Chu, Y. and Dong, M. (2009) Clonal Integration Improves Compensatory Growth in Heavily Grazed Ramet Populations of Two Inland-Dune Grasses. Flora-Morphology, Distribution, Functional Ecology of Plants, 204, 298-305. 
http://dx.doi.org/10.1016/j.flora.2008.03.003

[66] Esmaeili, M.M., Bonis, A., Bouzillé, J.B., Mony, C. and Benot, M.L. (2009) Consequence of Ramet Defoliation on Plant Clonal Propagation and Biomass Allocation: Example of Five Rhizomatous Grassland Species. Flora-Morphology, Distribution, Functional Ecology of Plants, 204, 25-33. http://dx.doi.org/10.1016/j.flora.2007.11.008

[67] Bulleri, F. and Malquori, F. (2015) High Tolerance to Simulated Herbivory in the Clonal Seaweed, Caulerpa cylindracea. Marine Environmental Research, 107, 61-65. http://dx.doi.org/10.1016/j.marenvres.2015.04.004

[68] Du, J., Wang, N., Alpert, P., Yu, M.J., Yu, F.H. and Dong, M. (2010) Clonal Integration Increases Performance of Ramets of the Fern Diplopterygium glaucum in an Evergreen Forest in Southeastern China. Flora-Morphology, Distribution, Functional Ecology of Plants, 205, 399-403. http://dx.doi.org/10.1016/j.flora.2009.12.018

[69] Xiao, Y., Tang, J., Qing, H., Ouyang, Y., Zhao, Y., Zhou, C. and An, S. (2010) Clonal Integration Enhances Flood Tolerance of Spartina alterniflora Daughter Ramets. Aquatic Botany, 92, 9-13. http://dx.doi.org/10.1016/j.aquabot.2009.09.001

[70] Chen, J.S., Lei, N.F. and Dong, M. (2010) Clonal Integration Improves the Tolerance of Carex praeclara to Sand Burial by Compensatory Response. Acta Oecologica, 36, 23-28. http://dx.doi.org/10.1016/j.actao.2009.09.006

[71] Xiao, Y., Tang, J., Qing, H., Zhou, C. and An, S. (2011) Effects of Salinity and Clonal Integration on Growth and Sexual Reproduction of the Invasive Grass Spartina alterniflora. Flora-Morphology, Distribution, Functional Ecology of Plants, 206, 736-741. http://dx.doi.org/10.1016/j.flora.2010.12.003

[72] Sun, S.C., Cai, Y.L. and An, S.Q. (2002) Differences in Morphology and Biomass Allocation of Scirpus mariqueter between Creekside and Inland Communities in the Changjiang Estuary, China. Wetlands, 22, 786-793. http://dx.doi.org/10.1672/0277-5212(2002)022[0786:DIMABA]2.0.CO;2

[73] Rojo, C., Martínez-Ruiz, C., Carramiñana, M. and Rodrigo, M.A. (2015) Foreseeable Global Warming Will Differentially Affect Chara vulgaris Populations from Different Altitudes. Aquatic Botany, 122, 20-26. http://dx.doi.org/10.1016/j.aquabot.2014.12.002

Submit or recommend next manuscript to SCIRP and we will provide best service for you:

Accepting pre-submission inquiries through Email, Facebook, LinkedIn, Twitter, etc.

A wide selection of journals (inclusive of 9 subjects, more than 200 journals)

Providing 24-hour high-quality service

User-friendly online submission system

Fair and swift peer-review system

Efficient typesetting and proofreading procedure

Display of the result of downloads and visits, as well as the number of cited articles

Maximum dissemination of your research work

Submit your manuscript at: http://papersubmission.scirp.org/

Or contact ns@scirp.org 